\title{
TES wt Allele
}

National Cancer Institute

\section{Source}

National Cancer Institute. TES wt Allele. NCI Thesaurus. Code C73549.

Human TES wild-type allele is located in the vicinity of 7q31.2 and is approximately $48 \mathrm{~kb}$ in length. This allele, which encodes testin protein, is involved in the mediation of signal transduction. 